prince, waged by an heroic tinker. What upsets this reading is that Christian states his allegiance to a King. Christian, still imperfectly assured of his election, is wounded in his "conversation" i.e. his conversion. He is rescued by a favourable biblical text. Indeed, the intertext is most specifically the extremely well-known Pauline passage towards the end of Ephesians about the armour of spiritual struggle against, note well, unearthly foes, and not oppressive earthly rules. While the text that pops into Christian's mind (just as texts popped into Bunyan's mind, as he records in the autobiography) is from elsewhere in St. Paul, the whole framework of allusion in the Apollyon episode is most certainly the Ephesians passage. The conflict is very much an internal one, although there might be sociological undertones. That there are such elsewhere is true: Mr Worldly-Wiseman is a patronising social superior, probably an Anglican Latitudinarian; Giant Despair is a landowner who locks up trespassers; the judges at Vanity Fair are a vengeful, restored royalist magistracy. The broad tradition of Bunyan criticism has always been well aware of these dimensions.

Let us finish nearer home, with Tiyo Soga and the Lovedale Mission. Isabel Hofmeyr is far more charitable than was Leon de Kock in his Civilizing Barbarians, although she acknowledges in passing, the case against missionary activity. Her information is most fascinating, starting with the early activity of van der Kemp with possible consequences in the Cattle-Killing, and with the indigenisation of Greatheart into Sifuba-Sibanzi, a folk hero. (Dare we whisper that "Bunyan's" Greatheart is the kind of pastor able to encourage pilgrims doubtful of the validity of their election?) Moving further north, we are told that Chief Albert Luthuli's father was John Bunyan Luthuli. Isabel Hofmeyr indicates that the great Zulu leader of the ANC seemed to be more secularised, but his autobiography, Let My People Go, is that of a devout man coming from a devout tradition. The Lovedale Mission gave birth to Fort Hare. Doubtless there were faults, even missionaries are fallen creatures, and usually creatures of their times, but the benefits were incalculable. We are the heirs of John Bunyan. Even if more inquiry is called for (and no book ever says it all) we are greatly indebted to Isabel Hofmeyr for her book.

Peter Titlestad

University of Pretoria

\section{Discovering Home. A selection of Works from the Caine Prize for African Writing 2002.}

Bellevue [SA]: Jacana, 2003. 240 pp. ISBN 1919931554

Although the cover of this interesting collection describes it as "A selection from the 2002 Caine Prize for African Writing", this applies to only five of its fourteen stories. The bulk of the tales are, in fact, "Stories from the African Writers' Workshop 2003" - by authors who were invited to a workshop held near Cape Town because their entries had been shortlisted for the Caine competition. The authors of this second group are referred to as "youngsters" although stories by the two facilitators (Veronique Tadjo and Peter Merrington) are also included here. The last page of the text usefully explains the rules for participation in the next Caine Prize competition.

The winning story is a heart-warming but by no means naïve account culminating in a huge family reunion: "In two days, we feel like a family. In French, Swahili, English, Kikuyu, Kinyarwanda, Kizanda and Ndebelo, we sing one song, a multi- 
tude of passports in our luggage" (26). This is the title story of the collection, but it is remarkable how appropriate this title is to most of the other stories in this collection even to the second story, whose protagonist is a young Nigerian woman who won an American green card in a competition. This poignant, complex story shows the protagonist's uncomfortable, baffled but undeniable feeling that in her relationship with a kind and generous white American there is nevertheless an inescapable flaw "Your worlds were wrong" (34).

A brilliant story, translated from French, is Florent Congo-Zotti's "Small Hells on Street Corners", in which the huge city market is itself a 'character', the sphere in which orphaned "man-children, culprit-children" (48) stand no chance of survival.

Rory Kilalea's "Zimbabwe Boy" is streetwise and poignant in taking on the issue of cross-race homosexuality in Zimbabwe - it depicts a fragile if somewhat unlikely encounter between a white farmer and a young black man who survives by "cruising". The only South African story among the Caine Prize group is by Allan Kolski Horwitz; ironically titled "Courageous and Steadfast", it examines the "post-liberation blues" of a small group gathered in Durban for an NGO conference: "Nomsa laughs (...) 'The minute you opened your mouth, I knew you were another of those disillusioned but still loyal Nkrumah types'" (73).

The sadness of postcolonial poverty and vulnerability runs like a refrain through most of the stories. A vivid detail in "Lagos, Lagos" (the first of the Workshop tales) refers to the sort of pushy Nigerian mothers "who husband-hunted for their daughters (...) forc[ing] them to marry rich ugly traders who spoke poor English and pulled their trousers up to their chests" (79) - a comic detail in a story of disillusioned hope. The surreal after-life story by Mbongisi Dyanti,
"The Witch of the Land", actually takes a strongly feminist, worldly stand; this is a South African story containing many brilliant, bitingly satirical moments and taking a sardonic position on the question "What is a witch"? (108).

Helon Habila's "My Uncle Hezekiel" tenderly and ironically recollects a ne'er-dowell: the exploitative, irresponsible and hopelessly alcoholic, yet lovable and humane Uncle. Rory Kilalea's story (in the second section) is spiced with juicy Kaaps (nonstandard Afrikaans) and set in Zimbabwe. It is punningly titled "Colours": both the dead 'listener' and the surviving (but dying) woman narrator were/are "coloured".

Horwitz's second story is called "The Adjournment" - this is a long and somewhat laboured account of a white lawyer who unexpectedly finds himself in jail, in the same vulnerable position as accused clients (from whom he is normally distanced). The central African civil wars and their attendant brutalities feature in "Do You Remember?" by Goretti Kyomuhende. A strange tale is Zachariah Rapoola's; I am not sure that its surrealism succeeds, however - the story fades out on a note of bafflement that seems intended to resonate. A "mysterious" woman evoked by a male writer/narrator features in this and the next story, "After Time"; here she is the narrator's own, dying mother - nursing her is both a terrible and a tenderly soothing experience: "I was (...) ridiculously happy. I couldn't wait for her to die"(199). This is an accomplished piece.

I like the sardonic final story in the collection, Binyavanga Wainnaina's "Ships in High Transit", which describes some tourists' "African encounter" from the indigenous perspective: "Ngugi is only recommended to those who came to Kenya to self-flagellate (...) because their cause and their self-esteem are one creature" (227-228). 
Finally, the stories by established writers featured in this collection range from Peter Merrington's rollicking Tarrantino-meetsthe-Cohen-brothers, a very American (tall!) tale, to Veronique Tadjo's and Shimmer Chinodya's stories of unfulfilling love unfortunately the latter are both rather disappointing pieces. But as the old man in Mbongisi Dyantyi's story warns, "The wisdom hidden in a story is for kings to discover; a fool sleeps for lack of understanding" (112).

Annie Gagiano

University of Stellenbosch

\section{Die onsigbares.}

E.K.M. Dido. Kaapstad: Kwela Boeke. 2003. 224 pp. ISBN 0-7957-0158-6.

As eerste nie-wit vroueskrywer wat die Afrikaanse prosa-arena betree, debuteer E.K.M. Dido in 1996 met Die storie van Monica Peters, gevolg deur Rugdraai en stilbly in 1997. Na laasgenoemde effense insinking, toon haar oeuvre weer' $n$ stygende lyn met 'n Stringetjie blou krale in 2000, met as hoogtepunt in haar oeuvre tot dusver die onlangs verskene Die onsigbares.

Die roman handel oor die lewens van vier egpare, maar sentreer veral om die ervarings van die vroue wie se mans in die huidige gewelddige postapartheid Suid-Afrika, in die jaar 2003 (54), in die polisiediens is. Op realistiese wyse word die destruktiewe fisiese sowel as psigiese gevolge van dié gevaarlike beroep op die gesinsverhoudinge en op individuele gesinslede uitgebeeld.

Die titel verwys in die eerste plek na die vrouens, wat nie slegs vir hulle afgetrokke en oorspanne mans "onsigbaar" word nie, maar ook vir die gemeenskap wat onbewus skyn te wees van die uitwerking van dié beroep op die gesinslewe (77 en 111). Wan- neer Joan Arries se huwelik sienderoë begin verbrokkel, plaas sy 'n advertensie in 'n koerant, en sit daarmee 'n telefoniese ondersteuningsnetwerk, waarby die onderskeie vroue dus vir mekaar "onsigbaar" bly, aan die gang. Ook die polisiemanne en vroue self is egter die "onsigbares", omdat hulle in hulle beroep noodgedwonge 'n beeld moet uitstraal van selfvertroue en bekwaamheid, maar tuis bang en onseker optree -' $n$ beeld wat eweneens vir die buitewêreld "onsigbaar" bly. Die titel hou ook die gedagte in van ' $n$ anonieme, ongeïdentifiseerde mag - die "hulle" (107) - wat die welstand van sowel die individu as die gemeenskap op allerlei vlakke bedreig.

Die sterk sosiale bewustheid wat uit die roman spreek is tiperend van Dido se prosaoeuvre. Hier lewer sy kommentaar op die algemene huidige landswye misdaad, maar vestig veral die aandag op bepaalde knelpunte rakende die polisiewêreld, soos die stres verbonde aan dié beroep, wat onder andere lei tot geestelike versteurings waarvan gesins- en selfmoorde getuig (87); die onoordeelkundige vrylating van misdadigers op borgtog; swak salarisse, wat medeverantwoordelik is vir korrupsie onder werknemers, ensovoorts. Met haar roman dwing sy die leser as ' $t$ ware om met ander oë na die polisieberoep te kyk in 'n poging om die "haatlike houding" (43) van die gemeenskap jeens die polisie te vervang met begrip.

Soos telkens in die postapartheidsroman, wys die individuele gevalle uit na die kollektiewe. Behalwe dat die vier egpare uit verteenwoordigende streke van die land kom (die Kaapse Vlakte, Oos-Londen; Soweto en Pretoria), word grense tussen ras, klas en geslag deurbreek om 'n deursnee samelewing te verteenwoordig. "'Problems kyk (immers) nie na colour nie'" (81), meen Joan se buurvrou. Gekleurd (Willem en Joan Arries; Shalon en Adam van Dyk); swart 